\title{
Dry Pint US
}

National Cancer Institute

\section{Source}

National Cancer Institute. Dry Pint US. NCI Thesaurus. Code C69116.

A traditional (non-SI) unit of volume equal to 1/8 dry US gallon, or approximately 0.550611 liter. 